\title{
Virtual Classroom: A Future of Education Post-COVID-19
}

\section{OPEN ACCESS}

Manuscript ID:

EDU-2020-08043238

Volume: 8

Issue: 4

Month: September

Year: 2020

P-ISSN: 2320-2653

E-ISSN: 2582-1334

Received: 17.06.2020

Accepted: 25.07.2020

Published: 01.09.2020

Citation:

Alhat, Swapnil. "Virtual

Classroom: A Future

of Education Post-

COVID-19." Shanlax

International Journal of

Education, vol. 8, no. 4,

2020, pp. 101-104.

DOI:

https://doi.org/10.34293/

education.v8i4.3238

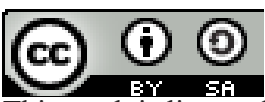

This work is licensed under a Creative Commons Attribution-ShareAlike 4.0 International License

\author{
Swapnil Alhat \\ Lecturer, Post-Graduate Department of English, LVH College, Nashik, Maharashtra, India \\ https://orcid.org/0000-0002-3668-6484
}

\begin{abstract}
Unexpectedly, COVID-19 has impacted and affected our world, and our world surely be the changing world when the dust of corona settles down. As we have learned to live within four walls without a cringe moreover online business would be a preferred way of shopping for a large section of the population to avoid human contact and stay protected from the lethal virus. The like virtual classrooms would be a new normal for our educational institutes. Some of the foreign universities like St. Andrews recently awarded a Ph.D. degree to the research scholar who defended his dissertation through video conferencing. Therefore that day is not far away from where classes would be run at the convenience of the students. Online courses are gradually catching the speed; there would come a time when the whole degree would be awarded to students without attending the university or college. Like this, in this paper, the researcher has endeavored the possibility of Virtual Classroom post-COVID-19 world.
\end{abstract}

Keywords: Telegraph, Telephone, Radio, Traditional Classroom and Virtual Classroom

\section{Introduction}

The year 2020 dawned with a lethal Corona virus that has threatened our existence moreover has disturbed our routine lives. If we go by the opinions of the scholars then this virus might change our whole way of life, means the way we used to live, ergo our socio-political worlds is going to affect by the COVID-19 not immediately but shortly. Because the whole is under a sort of house arrest that, i.e., Lockdown that not only has slowed down our lives but compelled us to find alternative sources to cope up with our lives and one such incident was took place on 14th of May 2020 when the social media giant twitter declared that its employees could work from home forever if they wish so.

\section{Twitter, in their statement, said like this}

"The past few months have proven we can make that work. So if our employees are in a role and situation that enables them to work from home and they want to continue to do so forever, we will make that happen."

[https://www.bbc.com/news/technology-52628119]

This is just a teaser of what lies ahead of us because twitter has 4000 employees globally and they are giving an option for their employees that if they wish they need not require attending the office regularly further, Google and Facebook have also apprised their employees that they can work from home till the year-end. Like this the world has started to change, and these changes we might see after two or three decades. 


\section{A Glance at Past Communicative Technologies Telegraph}

Samuel Morse (1792-8172) developed Telegraph in the early 1830 and 1840 s that then had revolutionized long-distance communications. It worked by transmitting electoral signals over a wire laid between the stations. The first telegraph message was sent in 1844 from Washington D.C to Baltimore, Maryland, US.

\section{Telephone}

An updated version of the telegraph was developed by Alexander Graham Bell in 1874 through an experiment. The problem was the telegraph was that it required Morse's code and could send only one message at a time. Ergo Bell started experimenting with multiple messages at a time using the same wire like this. The telephone was born and dominated till the birth of cellular phones.

\section{Radio}

Radios we use now only in our cars or in buses and probably don't pay attention to the babbling goes on their only become attentive when an interesting song is being played there. It is a little known fact today that the radios earlier used as a communicative device to contact ships at the seas. But after the WWI people started using radios for their private use and the rest is the history till the invention of the Television radios were considered as a thing of entertainment like today's TV.

Those above are the communicative tools used by our grandfathers and fathers, but we today no longer use it; to be precise, the generation born after 1990 has no idea about the telegraph further the generation after 2000 have no inkling of the telegraph, telephone, and radio. Since I remember very crystal clearly, i.e., 1995 that TV had started to become an everyday thing and by 2000 it had acquired the space in everyone's living room and families would sit around and watch their favorite serials. But TV came into the 1960s, and it took TV around three decades to become the household thing.

Like this, the internet has been there since 1960 circa but it took around four decades for the internet to become an everyday thing and now after six decades the internet has become an essential thing all around the world, moreover we cannot live without an internet on our cell phones. For instance, Ray Tomlinson was credited to invent the electronic mail in 1971, and today, email has around 2.6 billion active users and 4.6 billion accounts across the globe.

So, my argument here is that technology has always been there around us, but until it is used by everyone, it does not become popular of everyday things.

Today we are living in an era where we all are connected through one or the other social media account. Most of people have smartphone and internet so that the virtual class room could be the future of our education system.

\section{Traditional Classroom}

So what is the traditional classroom? The answer is pretty simple, where a teacher teaches students in a room that is called as a traditional classroom. Not very long back ago, many villages in India did not have the schools with classrooms, the schools used to be an open school where a teacher would conduct his classes under the tree by the river or on a platform under the shade but without the walls.

Now by 2020, the scenario has got changed; most of the schools have proper infrastructure like building with a roof and separate classrooms for each standard, not like earlier where all the students would sit in one class, and there would be only one teacher teaching them simultaneously. The students go to their school away from their home so they could concentrate on their study without hindrance, and where one after another teacher would come to teach them.

\section{Virtual Classroom}

What is a virtual classroom? A virtual classroom is not so different than the traditional classroom; in a virtual class, there is a teacher who is teaching but not in the class but in front of a camera of a computer somewhere, and the students participate in his class sitting in their room in front of the computer. In the virtual classrooms there can be an interactive session like a traditional classroom, students and teachers can interact. Virtual Classroom can be defined as 
"A collaborative web conferencing tool with an online white board, breakout rooms, and screen sharing capabilities, for teachers and tutors who want to conduct highly interactive live online teaching sessions."

[https://www.vedamo.com/virtual-classroom/]

\section{Advantages of Virtual Classroom (VC)}

1. VCs are more helpful for the students who cannot attend the schools or college on a regular basis.

2. It gives an advantage for the student to attend classes from anywhere in the world.

3. It also reduces the classroom phobia of students.

4. VC is the personalized learning; students can learn at their will.

5. It gives students and teacher a world wide exposure.

6. VCs are effective and efficient, and it consumes less time, unlike of traditional school or college.

7. If having necessary equipment, it would provide a golden opportunity to the students from the remote villages and area.

8. It gives access from anywhere in the world, any time as per the schedule of the learner.

9. It also sharpens digital skills.

\section{Disadvantages of Virtual Classroom (VC)}

1. One of the main disadvantages is that it requires a Computer and a steady internet connection.

2. It is also criticized for its technology and undemocratized nature.

3. Requires technological literacy.

4. Perception is that it is made for only urban students.

\section{Conclusion}

What could be the world after COVID-19? No one at this moment has the answer because we don't know that yet! CVID-19 has changed our world, and people are scared of coming out of their homes virtual classrooms could be the future schools and colleges of our world. If we look at the history of the technology, then we come to know that it takes decades for a technology to be everyday thing ergo VCs are taking a baby step today, but after a decade, it might replace the traditional classroom because it won't be like a robot teaching.

\section{References}

"7 Benefits of Virtual Classroom." Walden University, https://www.waldenu.edu/programs/resource/ seven-benefits-of-a-virtual-classroom.

"A brief history of email: dedicated to Ray Tomlinson." Pharsee, https://phrasee.co/abrief-history-of-email.

"A Brief History of the Internet." Science Node, 2017, https://sciencenode.org/feature/a-briefhistory-of-the-internet-.php.

"A Brief History of the Internet" University System Georgia, https://www.usg.edu/galileo/skills/ unit07/internet07_02.phtml

Bloom, Zack. "The History of Email." Cloudfare, 2017, https://blog.cloudflare.com/the-historyof-email.

Broth, David E. “Telephone.” Britannica, https:// www.britannica.com/technology/telephone.

"Coronavirus: Twitter allows staff to work from home 'forever'." BBC, 2020, https://www. bbc.com/news/technology-52628119.

Craig, William. "The History of Internet in a Nutshell." WebFx, 2019, https://www.webfx. com/blog/web-design/the-history-of-theinternet-in-a-nutshell.

Hann, David. "Telegram Brief History, Stop.” The Open University, 2014, https://www.open. edu/openlearn/science-maths-technology/ computing-and-ict/information-andcommunication-technologies/telegram-briefhistory-stop.

Hiltz, Starr Roxanne. The Virtual Classroom: Learning without Limits via Computer Networks. Intellect, 1994.

"History of the Radio: From Inception to Modern Day." Tech Wholesale, https://www. techwholesale.com/history-of-the-radio.html. "Introduction to Virtual Class Room." G-CUBE, https://www.gc-solutions.net/resources/ articles/introduction-to-virtual-class-room.

Leiner, Barry M. et al. "Brief History of the Internet." Internet Society, 1997, https:// www.internetsociety.org/internet/historyinternet/brief-history-internet.

Morris, Jason. "History of the Telephone." Nationalitpa, https://www.nationalitpa.com/ history-of-telephone. 
Morrison, Kate. "Why is Virtual Classroom better than a real one." E-Learning Industry, 2016, https://elearningindustry.com/virtualclassroom-better-real-one.

Smith, Frank D. "Virtual Classrooms: A Vision of the Future of Teachers Training." Ed Tech, 2016, https://edtechmagazine.com/higher/ article/2016/03/virtual-classrooms-visionfuture-teacher-training.

Sterling, Christopher H. and Randy Skretvedt. "Radio Broadcasting." Britannica, https:// www.britannica.com/topic/radio.
"Telegram Passes into History." WIRED, 2006, https://www.wired.com/2006/02/telegrampasses-into-history.

“The History of Telephone." Mitel, https://www. mitel.com/articles/history-telephone.

Vadakkanmarveettil, Jyotsna. "Virtual Classrooms: The Future of Education.” Analytics Training, 2011, https://analyticstraining.com/virtual_ classroom.

"Virtual Classroom." VEDAMO, https://www. vedamo.com/virtual-classroom.

\section{Author Details}

Swapnil Alhat, Lecturer, Post-Graduate Department of English, LVH College, Nashik, Maharashtra, India 